Marquette University

e-Publications@Marquette

$10-1-2016$

\title{
Does Eco-labeling of Services Matter? Evidence from Higher Education
}

Daniel C. Hickman

University of Idaho

Andrew G. Meyer

Marquette University, andrew.meyer@marquette.edu

Published version. The B.E. Journal of Economic Analysis \& Policy, Vol. 16, No. 4 (October 2016). DOI. (C) 2016 Walter de Gruyter. Used with permission. 


\title{
Does Eco-labeling of Services Matter? Evidence from Higher Education
}

\author{
${ }^{1}$ Department of Business, University of Idaho, 875 Perimeter Dr. MS 3161, Moscow, ID 83844, USA, E-mail: dhick- \\ man@uidaho.edu \\ ${ }^{2}$ Department of Economics, Marquette University, 606 N. 13th St David Straz Hall, Milwaukee, WI 53151, USA, E-mail: an- \\ drew.g.meyer@marquette.edu
}

\begin{abstract}
:
Eco-labeling of services has become increasingly common, yet little empirical evidence exists concerning its effectiveness. We address this gap in the literature by analyzing a highly visible eco-label, the American College and University Presidents' Climate Commitment (ACUPCC), in the sector of higher education. We match information about the ACUPCC to the US Department of Education IPEDS database to examine the impact of signing on student applications, admissions, and enrollment. We mainly utilize a difference-in-difference approach to identify the effects of interest but confirm results with an interrupted time series model. We find that signing the ACUPCC increases applications and admitted students by $2.5-3.5 \%$. However, the evidence regarding enrollment is weaker with only some specifications finding increases of around 1-2\%. Overall, there is considerable heterogeneity across sectors and selectivity of the institutions. These results show that, at the minimum, voluntary and information-based approaches (VIBAs) for services can be effective in generating visibility and influencing less-costly consumer behavior.
\end{abstract}

Keywords: eco-labeling, information provision, educational economics, higher education, VIBAs

DOI: 10.1515/bejeap-2016-0050

\section{Introduction}

Examples of eco-labeled goods and services are becoming more and more common in the marketplace. This practice is typically considered to be an information provision program, in which the label conveys the environmental benefits of the product. In contrast to the traditional approaches to environmental regulation that set mandatory standards or attempt to price the externality, eco-labeling is a voluntary and information-based approach (VIBA) (Bjorner, Hansen, \& Russell, 2004; Kotchen, 2013; Segerson, 2013 ). Such voluntary programs require some commitment to improve environmental performance beyond those required by existing environmental regulations, and continue to grow in popularity, with hundreds of voluntary programs in effect around the world (Morgenstern and Pizer 2007 ). Theoretical work on the topic has shown that the provision of such information can positively impact the environmental behavior of individuals (Kennedy, Laplante \& Maxwell, 1994; Petrakis, Sartzetakis \& Xepapadeas, 2005 ) and even reduce the required environmental tax rate (Sartzetakis, Xepapadeas, and Petrakis 2012 ). Likewise, some have argued that market forces for eco-labeled products could lead to socially beneficial outcomes through allowing consumers to express their preferences for environmentally-friendly products (Lyon \& Maxwell, 2002; Podhorsky, 2008 ).

Empirical work on the topic has yielded limited evidence suggesting the eco-labeling of goods can impact consumer behavior in both stated preference (Loureiro \& Lotade, 2005; Loureiro, McCluskey \& Mittelhammer, 2001 ) and revealed preference situations (Bjorner, Hansen, \& Russell, 2004; Nimon \& Beghin, 1999; Teisl, Roe \& Hicks, 2002 ). However, surprisingly little work has been done specifically regarding the eco-labeling of services. ${ }^{1}$ In addition, several recent studies argue that VIBAs can be better understood using club theory, where members voluntarily join the green club to generate credibility and/or visibility (Kotchen, 2013; Potoski \& Prakash, 2005; Potoski \& Prakash, 2009; van't Veld \& Kotchen, 2011 ). To this point, however, there is a lack of empirical evidence of any such visibility impacts. In this paper, we seek to fill these gaps in the literature by analyzing one major service sector, higher education.

Since 2006, almost 700 institutions of higher education (hereafter IHEs) have signed the American College and University Presidents' Climate Commitment (ACUPCC). ${ }^{2}$ The ACUPCC is a highly visible signal of the environmental commitment of IHEs that requires signatories to take immediate steps to reduce greenhouse gases and develop a plan for becoming climate neutral. We match the information about signatories to the US 
Department of Education's Integrated Postsecondary Education Data System (IPEDS) database (2002-2013) to create a 12-year panel of essentially all US 4-year-degree-granting IHEs in the public and private not-for-profit sectors. We then utilize a difference-in-difference framework to identify the impact on several outcome variables of interest including the number of applications, admitted students, and enrolled students. Furthermore, we estimate an interrupted time series model as a robustness exercise and find similar results.

On average, we find that signing the ACUPCC increases student applications by around $2.5 \%$ to $3 \%$. There is also evidence that IHEs then capitalize on these extra applications by similarly increasing the number of admitted students. However, there is only weak evidence that these extra admissions translate into higher enrollment. Our point estimates suggest that enrollment increases by 1 to $2 \%$ on average, but these enrollment estimates are significant at conventional levels in only some of the specifications. Examining the subsamples of public and private IHEs, we see that most of these effects are being driven by the private IHEs. We also find that less selective IHEs experience stronger effects compared to more selective IHEs.

These findings are an important contribution to the literature in that previously there had only been anecdotal evidence that an IHE's environmental commitment matters. ${ }^{3}$ We are not aware of any prior evidence regarding an IHE's environmental commitment affecting the enrollment decision of those admitted. Our results indicate that, while the commitment to the environment is a factor that draws interest in the form of applications, it may not be a big enough factor to sway an individual's final decision of where to attend overall. However, the stronger enrollment results for less selective IHEs indicate that at least a subset of institutions do experience an increase in enrollment from signing.

A large theoretical literature explores firms' motivations for adopting a VIBA. This literature tries to reconcile the standard economic theory, which suggests that individuals and firms will not be willing to incur much private cost for products that provide benefits to everybody, ${ }^{4}$ with the empirical observation of the proliferation of VIBAs. Arora and Gangopadhyay (1995) demonstrate that public recognition can be an important theoretical motivator to adopt a VIBA because it allows the firm to appeal to environmentally focused consumers with a higher willingness to pay. Segerson and Miceli (1998) and Maxwell, Lyon, and Hackett (2000) show that firms may participate to preempt government intervention and hence save on abatement costs. Graff Zivin and Small (2005) argue that firms are essentially competing with traditional not-for-profits when they voluntarily improve environmental performance beyond regulations and are effectively soliciting contributions from customers and shareholders. Baron (2007) similarly shows that some entrepreneurs are willing to trade away financial gains for social satisfaction or warm glow. Finally, a pair of papers examine the private provision of public goods showing that such provision can be profit-maximizing because of the premium that consumers are willing to pay (Bagnoli \& Watts, 2003; Besley \& Ghatak, 2007 ). However, there is not as much empirical work in this area documenting the benefits of adopting a VIBA. ${ }^{5}$

Most of the empirical work concerning VIBAs has concentrated on the supply side issue of their environmental effectiveness. ${ }^{6}$ Much of this literature analyzes the environmental impacts of the EPA's 33/50 program. Results are mixed with some studies suggesting that the program reduced toxic emissions (Khanna \& Damon, 1999; Sam, Khanna \& Innes, 2009 ) and others finding no effect or even a positive effect on emissions (GamperRabindran, 2006; Vidovic \& Khanna, 2007). Similarly, King and Lenox (2000) find no evidence that the chemical industry's Responsible Care program reduces participants' environmental performance and Welch, Mazur, and Bretschneider (2000) find that the adoption of the U.S. Department of Energy's Climate Challenge Program has no effect on emissions. Morgenstern, Pizer, and Shih (2007) utilize propensity score matching methods to establish a control group for difference-in-difference estimation of the energy usage effects of the EPA Climate Wise program and find mainly mixed and insignificant results. Another strand of the empirical literature has focused on the factors that affect the probability of a firm participating in a VIBA, with again much of evidence stemming from the EPA's 33/50 program (Arora \& Cason, 1996; Arora \& Cason, 1995; Khanna \& Damon, 1999). However, there is less research in the economics literature evaluating the impact of VIBAs on consumer demand for the product. One notable exception is the group of papers documenting price premiums in the residential (Brounen \& Kok, 2011; Deng, Li \& Quigley, 2012 ) and commercial (Eichholtz, Kok \& Quigley, 2013; Eichholtz, Kok \& Quigley, 2010; Fuerst \& McAllister, 2011a; Fuerst \& McAllister, 2011b ) real estate markets due to energy labels. Ultimately, the long-run success of eco-labeling programs requires that firms receive some benefit to offset the additional abatement cost.

This research also contributes to the literature that explores the determinants of demand for higher education. Most commonly, research in this area focuses on factors such as price (Curs \& Singell, 2002; Neill, 2009; Soo \& Elliott, 2010 ) and financial aid (DesJardins, Ahlburg \& McCall, 2006; Dynarski, 2003; Heller, 1999 ). Many of the more recent studies in the area, however, have been focused on identifying other attributes that affect the application and admission decisions of potential students. Some of the factors that have been examined include rankings and reputation (Alter \& Reback, 2014; Luca \& Smith, 2013 ), spending on student services (Jacob, McCall, and Stange 2013 ), athletic success (Pope and Pope 2009 ), and application processes (Liu, Ehrenberg 
\& Mrdjenovic, 2007; Smith, Hurwitz \& Howell, 2015 ). We add this line of research by considering how an institution's commitment to the environment influences student application and enrollment decisions.

\section{Data Description}

We utilize two main data sources for this analysis, the IPEDS database and the ACUPCC reporting database. ${ }^{7}$ The IPEDS data contain institution-level information from the National Center for Education Statistics (US Department of Education. Institute of Education Sciences, National Center for Education Statistics 2015 ). Any IHE that participates in any federal financial assistance program in the United States is required to complete the IPEDS surveys on an annual basis. As a result, there is a large amount of information available on a consistent annual basis for nearly every IHE. ${ }^{8}$ In our analysis, we focus on information from the academic years 2002-2003 through 2013-2014. ${ }^{9}$ The time period for the analysis was selected to include a similar amount of information from the periods before and after the emergence of the ACUPCC.

The primary information that we obtain from the IPEDS database relates to the applications and admission variables that represent the outcomes in our empirical analysis. This includes variables for the number of first-time, degree-seeking undergraduates who applied, were admitted, and enrolled each fall semester. The enrollment variable includes students that were enrolled full or part-time at the institution. While we implement a fixed effects analysis to control for time-invariant factors unique to each IHE, we also collect a handful of variables that vary within institutions over time, and that might be influential in student decisions. To account for how price influences student behavior, we use IPEDS variables for the undergraduate application fee charged in a given year, as well as in-state and out-of-state tuition. To account for how the quality of a school may be changing, we follow Pope and Pope (2009) in collecting information on the average salary of professors. ${ }^{10}$ Previous research (Smith, Hurwitz, and Howell 2015 , for example) shows that belonging to the Common Application significantly affects applications. Some IHEs join the Common Application during the period of our panel so we include membership in the Common Application as a potentially important time-variant control. ${ }^{11}$ Finally, we supplement the IPEDS information by including variables for the number of high school graduates (from the Digest of Education Statistics), and the real income per capita (from the Census) in the state in which each IHE is located.

The ACUPCC originated out of planning sessions at the October 2006 meetings of the Association for the Advancement of Sustainability in Higher Education (AASHE). A group of IHE presidents, Second Nature, ecoAmerica, and AASHE collaborated to generate the commitment and 12 presidents became founding signatories in December 2006 (ACUPCC Mission and History 2014). As previously mentioned, almost 700 IHEs have since signed the ACUPCC. In signing this commitment, IHEs agree to 1) complete an emissions inventory, 2) within 2 years, set a target date and interim milestones for becoming climate neutral, 3) take immediate steps to reduce greenhouse gas emissions by choosing from a list of short-term actions, 4) integrate sustainability into the curriculum and make it part of the educational experience, and 5) make the action plan, inventory and progress reports publicly available.

In order for the signing of this commitment to plausibly affect applications and admissions decisions, it must be the case that students are aware of the commitment. There are several avenues by which students may become aware of this information. First, the media has provided extensive coverage on this commitment since its inception. Until recently the ACUPCC website maintained an archive of several hundred media stories dated 2006-2014 related to the ACUPCC and its signatories. Any prospective student conducting an internet search of an IHE's name was therefore liable to come across any number of these stories. Also, perusal of a signatory IHE's website will often provide information about its ACUPCC signatory status. ${ }^{12}$ Once aware of the ACUPCC, interested parties can find all of the relevant information about signatories of the ACUPCC on its publicly available ACUPCC Reporting System website. Finally, The Princeton Review's Guide to Green Colleges clearly identifies whether or not each IHE in the guide had signed the ACUPCC from the inception of the guide in 2010 through the end of our study period.

We limit our sample to four-year degree granting public and private-not-for-profit IHEs. ${ }^{13}$ We further clean the data to remove IHEs that report implausibly large changes in applications in two consecutive years. To do this we examine the distribution of year-to-year percentage change in applications among the sample IHEs. The top 1 percentile of observations display a 1 year increase that is greater than a $114.43 \%$ in applications and the bottom 1 percentile of observations are characterized by a 1 year decrease of more than $47.54 \%$. We remove all observations from the IHEs falling into either the top or bottom percentile. Not counting 13 singleton observations, which are dropped from the institution fixed-effects analysis, the final sample for analysis contains 12,353 observations from 1,121 IHEs spanning the years 2002-2013. Table 1 shows summary statistics for these 12,353 observations. We note that approximately $16 \%$ of the observations come from ACUPCC IHEs in years 
where they have signed on to the commitment. We also note that there is substantial variation among IHEs in their number of applications, students admitted, and students enrolled; the standard deviation is slightly larger than the mean for these three variables.

Table 1: Summary statistics.

\begin{tabular}{|c|c|c|c|c|c|c|}
\hline Variable & Mean & Std. Dev. & Min & Median & Max & Obs \\
\hline Applications & $5,764.10$ & $7,366.89$ & 9 & 3,086 & 72,676 & 12,353 \\
\hline Admissions & $3,307.21$ & $3,821.01$ & 4 & 1,938 & 35,815 & 12,353 \\
\hline Enrollment & $1,105.19$ & $1,250.28$ & 1 & 602 & 9,082 & 12,350 \\
\hline Signed & 0.16 & 0.37 & 0 & 0 & 1 & 12,353 \\
\hline $\begin{array}{l}\text { Common } \\
\text { application }\end{array}$ & 0.27 & 0.44 & 0 & 0 & 1 & 12,353 \\
\hline $\begin{array}{l}\text { In-state } \\
\text { tuition* }\end{array}$ & 18.51 & 12.55 & 0 & 19.34 & 47.95 & 12,313 \\
\hline $\begin{array}{l}\text { Out-of-state } \\
\text { tuition* }\end{array}$ & 22.31 & 9.42 & 0 & 21.32 & 47.95 & 12,313 \\
\hline $\begin{array}{l}\text { HS graduates } \\
\left(1,000^{\prime} \mathrm{s}\right)\end{array}$ & 111.28 & 94.46 & 3.93 & 74.78 & 430.29 & 12,353 \\
\hline $\begin{array}{l}\text { Income per } \\
\text { capita** }\end{array}$ & 44.31 & 6.62 & 30.52 & 43.45 & 78.31 & 12,353 \\
\hline $\begin{array}{l}\text { Undergradu- } \\
\text { ate } \\
\text { application } \\
\text { fee }\end{array}$ & 47.17 & 21.54 & 0 & 45.63 & 173.17 & 12,023 \\
\hline $\begin{array}{l}\text { Average } \\
\text { professor } \\
\text { salary* }\end{array}$ & 95.68 & 26.11 & 13.23 & 88.60 & 232.48 & 11,197 \\
\hline
\end{tabular}

${ }^{*}$ indicates measured in 1,000's of constant 2014 dollars. Undergraduate application fee is measured in constant 2014 dollars. High school graduates and income per capita are measured for the state in which the institution is located. All of other variables are at the institution level.

The "Signed" column of Table 2 provides a description of the timing of the signing of the ACUPCC for sample IHEs. Our sample contains 376 IHEs that sign the ACUPCC and report admissions variables to IPEDS. Table 2 shows that the largest number of sample signatories signed on to the ACUPCC in 2007. However, a lesser number of IHEs continued to sign the ACUPCC throughout the time period of our panel. We also note that there are nearly equal numbers of public and private not-for-profit IHEs signing the agreement during the time period of our sample. A challenge to identifying the impact of the signing of the ACUPCC is the timing of the application cycle. IHEs vary in their application deadlines, with some deadlines as early as November (for the following fall) and some as late as August (for that fall). Many IHEs have continuous or rolling application deadlines rather than specific months. We make the assumption that an IHE that signs the ACUPCC in the first 6 months of the year (by the end of June) could affect applications for the upcoming fall semester. An IHE signing the ACUPCC in the second 6 months of the year (July through December) would not affect applications until the following fall semester. ${ }^{14}$ Based on our assumption that signing in the first half of the year affects that fall's applications, the "Effective" column of Table 2 provides a description of the variation in the timing of potential impact among the signatory IHEs.

Table 2: Timing of the signing of the ACUPCC.

\begin{tabular}{lllllll}
\hline Year & Signed & $\begin{array}{c}\text { Overall } \\
\text { Effective }\end{array}$ & Signed & $\begin{array}{c}\text { Public } \\
\text { Effective }\end{array}$ & Signed & $\begin{array}{c}\text { Private } \\
\text { Effective }\end{array}$ \\
\hline 2006 & 9 & 0 & 6 & 0 & 3 & 0 \\
2007 & 230 & 173 & 118 & 94 & 112 & 79 \\
2008 & 66 & 110 & 37 & 54 & 29 & 56 \\
2009 & 20 & 36 & 12 & 20 & 8 & 16 \\
2010 & 17 & 16 & 6 & 9 & 11 & 7 \\
2011 & 15 & 18 & 6 & 7 & 9 & 11 \\
2012 & 9 & 7 & 2 & 1 & 7 & 6 \\
2013 & 10 & 16 & 4 & 6 & 6 & 10 \\
Total & 376 & 376 & 191 & 191 & 185 & 185 \\
\hline
\end{tabular}




\section{Empirical Strategy}

The IPEDS database provides information on the universe of IHEs, which means we are able to build a panel including both signatories and non-signatories. Clearly, the institution-level decision to become a signatory could be endogenous; many institutional characteristics are unobservable to the researcher and potentially correlated with both the signing of the ACUPCC and the outcome measures of interest such as applications and enrollment. A failure to address these unobservable characteristics could lead to biased results regarding the effects of signing the ACUPCC. Also, as noted by Morgenstern and Pizer (2007), the challenge in the program evaluation of VIBAs is finding a credible baseline of what would have occurred absent the adoption of the program. The two general approaches are to either compare participants to a similar group of nonparticipants or to construct a business-as-usual forecast using data on only the participants. We focus on the former approach with a random-growth difference-in-difference estimator. We also implement the latter approach with an interrupted time-series estimator as a robustness check in Section 5.

We utilize the regression-adjusted version of the difference-in-difference (hereafter DID) estimator for multiple time-periods (Angrist \& Krueger, 1999; Imbens \& Wooldridge, 2009). IHE $i$ belongs to a group, $G_{i} \in\{0,1\}$ (where group 1 is the treatment group of signatories), and is observed in time period $t \in\{2002,2003, \ldots, 2013\}$. The regression equation is

$$
Y_{i t}=\alpha+\tau S_{i t}+X_{i t}{ }^{\prime} \delta+\gamma_{i}+\lambda_{t}+\varepsilon_{i t} .
$$

where $S_{i t}$ is an indicator for being a signatory in a post-signing year, $X_{i t}$ is a vector of IHE characteristics, $\gamma_{i}$ is a time-invariant IHE-specific fixed effect potentially correlated with $G_{i}$, and $\lambda_{t}$ is a set of year fixed effects.. The coefficient of interest, $\tau$, is the DID treatment effect. As noted by Angrist and Krueger (1999) , controlling for IHE characteristics changes our estimate of $\tau$ only if $S_{i t}$ and $X_{i t}$ are correlated, conditional on IHE and year fixed effects. Identification of a causal effect in [1] requires that signatories and non-signatories would have experienced the same trends in the outcome variables had the signing of the ACUPCC not occurred. This may not necessarily be the case. Thus, we make a modification to [1] to allow for IHE-specific linear trends, $\varphi_{i}$, and have

$$
Y_{i t}=\alpha+\tau S_{i t}+X_{i t}{ }^{\prime} \delta+\gamma_{i}+\lambda_{t}+\varphi_{i} t+\varepsilon_{i t}
$$

Equation [2] is often referred to as the random-trend model when the dependent variable is in level form and the random-growth model when the dependent variable is in log form (Wooldridge 2005 ). It is possible that other unobservable IHE factors changed at the same time as the ACUPCC signing status. This could be problematic for our identification of the causal effects of signing if these unobservable factors also affect our outcomes of interest. We return to this issue in more depth in Section 5.2.

Equation [2] is our main econometric specification for the DID estimation. Hence, we are identifying the treatment effect by comparing deviations from the IHE-specific trend in the pre- and post-signatory years, relative to the aggregate time effects. We estimate this model for the outcomes of (logged) applications, admissions, and enrollment. We log the dependent variables for two reasons. First, the distributions are positively skewed so utilizing the untransformed variables could overweight large schools relative to small schools (Pope and Pope 2009 ). Secondly, we believe the signing of the ACUPCC is likely to affect the outcome variables by a given percentage rather than a certain level across IHEs. Recall that IHEs are first able to sign the ACUPCC in 2006 (with the signing first affecting the fall 2007 cohort). Nevertheless, the data are available so we include observations dating back to fall 2002. This gives more information on the pre-signatory time-period and thus helps to establish the school-specific growth rates. ${ }^{15}$ We cluster standard errors at the institution level for all regressions.

Our estimate of $\tau$ corresponds to the estimate of the average treatment effect (ATE) if the treatment indicator, $S_{i t}$, is exogenous given the unobserved IHE-level time-invariant heterogeneity and IHE-level growth rate. There is a tradeoff here; the results apply to the general population of IHEs only if we utilize a sample that is representative of the population. On the other hand, the required conditional exogeneity may be more believable with a subsample of IHEs that are more homogenous. Therefore, we estimate our model with three different samples to test the impact of the ACUPCC signing on demand for an IHE. To begin, we compare across a set of IHEs that are otherwise identified as having a commitment to the environment, which forms control and treatment groups that are reasonably similar. To do this, we define our sample to be the IHEs listed in the 2015 Princeton Review's Guide to Green Colleges. ${ }^{16}$ Among these schools, some sign the ACUPCC during the 
time period examined, and some do not. In this way, we are able to see if indicating this specific commitment impacts the decisions of consumers among a set of schools otherwise deemed to be environmentally friendly. Secondly, we focus only on signatories, and identification of the signing's impact depends on variation in the timing of the ACUPCC signing. ${ }^{17}$ The results for this subsample are interpreted as the impact of signing the ACUPCC, conditional on being a member of the signatory group. Finally, we utilize the full sample of IHEs that grant 4-year degrees in the public and private not-for-profit sectors to establish counterfactual common time-effects. In each of these cases, our empirical strategy involves controlling for IHE-specific time trends and time-invariant unobservable characteristics.

Appendix Table 11 provides descriptive statistics for each of the different samples we utilize in our DID analysis. The values in this table are drawn from the 2005-2006 academic year, so that we can examine the similarity of the controls in each of our sample specifications with the corresponding treatment group before the treatment occurs. For each of the three comparison groups, we present the mean values for several variables, and then indicate when there are significant differences in the means between groups. ${ }^{18}$ There are few significant differences of note in both our Green Guide and signatory samples. When we compare those that sign to the universe of 4-year IHEs we see highly significant differences in nearly every variable. As subsequently demonstrated in our first sets of results, the estimates tend to be similar when using the various comparison groups. For the sake of brevity, we focus on the sample of all 4-year IHEs for subsequent results testing for heterogeneity, as well as our robustness checks and falsification tests.

\section{Results}

We first present the main results in Section 4.1 and then investigate heterogeneity in Section 4.2. Subsequently, we show a variety of robustness checks in Section 5.

\subsection{Main Results}

We begin our examination of the empirical results by looking at the impact of ACUPCC signing on the number of students applying to an IHE. These results are presented in Table 3. For each of the samples, we first present results for a simplified specification that includes no control variables beyond the fixed effects and IHE-specific linear trends. ${ }^{19}$ We then present the results from estimating our full model which includes the state and IHElevel control variables. The first two columns present the results for the sample of schools listed in the Princeton Review's Guide to Green Colleges. Columns 3 and 4 present our sample that includes only schools that sign the ACUPCC agreement over the period sampled, and exploits variation in the timing of signing, and columns 5 and 6 present the results for the full sample of 4-year IHEs. In each case, it is estimated that there is a positive and significant impact on applications. The magnitudes of the estimated impact are quite similar in each case, with an estimated increase of between $2.65 \%$ and $3.13 \%$, depending on the specification. ${ }^{20}$

Table 3: Regression results: applications.

\begin{tabular}{|c|c|c|c|c|c|c|}
\hline & (1) & $\begin{array}{l}(2) \\
\text { guide }\end{array}$ & Signatories & $\begin{array}{l}(4) \\
\text { tories }\end{array}$ & (5) & $\begin{array}{l}\text { (6) } \\
\text { or IHEs }\end{array}$ \\
\hline Signed & $\begin{array}{l}0.0281^{* *} \\
(0.0138)\end{array}$ & $\begin{array}{l}0.0294^{* *} \\
(0.0146)\end{array}$ & $\begin{array}{l}0.0265^{*} \\
(0.0141)\end{array}$ & $\begin{array}{l}0.0297^{* *} \\
(0.0151)\end{array}$ & $\begin{array}{l}0.0295^{* * *} \\
(0.0112)\end{array}$ & $\begin{array}{l}0.0313^{* * *} \\
(0.0120)\end{array}$ \\
\hline $\begin{array}{l}\text { Common } \\
\text { application }\end{array}$ & & $\begin{array}{l}0.0722^{* * *} \\
(0.0227)\end{array}$ & & $\begin{array}{l}0.0911^{* * *} \\
(0.0233)\end{array}$ & & $\begin{array}{l}0.0747^{* * *} \\
(0.0162)\end{array}$ \\
\hline $\begin{array}{l}\text { HS graduates } \\
(1,000 \text { 's })\end{array}$ & & $\begin{array}{l}0.00236^{* * *} \\
(0.000912)\end{array}$ & & $\begin{array}{l}0.00379^{* * *} \\
(0.00112)\end{array}$ & & $\begin{array}{l}0.00146^{* *} \\
(0.000726)\end{array}$ \\
\hline $\begin{array}{l}\text { Income per } \\
\text { capita } \\
\left(1,000^{\prime} \mathrm{s}\right)\end{array}$ & & $0.0114^{* *}$ & & $0.00972^{*}$ & & 0.00501 \\
\hline $\begin{array}{l}\text { Undergradu- } \\
\text { ate } \\
\text { application } \\
\text { fee }\end{array}$ & & $\begin{array}{l}(0.00521) \\
0.000223\end{array}$ & & $\begin{array}{l}(0.00533) \\
-0.000318\end{array}$ & & $\begin{array}{l}(0.00331) \\
-0.000679 *\end{array}$ \\
\hline
\end{tabular}




\begin{tabular}{|c|c|c|c|c|c|c|}
\hline \multicolumn{2}{|l|}{$\begin{array}{l}\text { Ln in-state } \\
\text { tuition } \\
(1,000 \text { 's })\end{array}$} & \multicolumn{2}{|l|}{$-0.0952^{*}$} & \multicolumn{2}{|l|}{-0.0117} & -0.0298 \\
\hline $\begin{array}{l}\text { (lagged } 1 \\
\text { year) }\end{array}$ & & $(0.0554)$ & & $(0.0729)$ & & $(0.0372)$ \\
\hline $\begin{array}{l}\text { Ln out-state } \\
\text { tuition } \\
\left(1,000^{\prime} s\right)\end{array}$ & & 0.0282 & & -0.0164 & & 0.0237 \\
\hline $\begin{array}{l}\text { (lagged } 1 \\
\text { year) }\end{array}$ & & $(0.0236)$ & & $(0.0323)$ & & $(0.0243)$ \\
\hline $\begin{array}{l}\text { Ln Avg. Prof. } \\
\text { Salary } \\
\left(1,000^{\prime} \text { s }\right)\end{array}$ & & 0.141 & & 0.0883 & & -0.0466 \\
\hline $\begin{array}{l}\text { (lagged } 1 \\
\text { year) }\end{array}$ & & $(0.0955)$ & & $(0.0989)$ & & $(0.0566)$ \\
\hline Observations & 3,648 & 3,377 & 4,205 & 3,854 & 12,353 & 11,216 \\
\hline$R$-squared & 0.990 & 0.989 & 0.988 & 0.987 & 0.987 & 0.987 \\
\hline
\end{tabular}

Notes: table presents regression results from models in which dependent variable is In of applications. Samples vary as described in text. Standard errors, clustered at IHE level, presented in parentheses. All specifications include IHE fixed effects, IHE-specific linear trends, and year fixed effects. All monetary variables measured in constant 2014 dollars. * denotes significance at 0.10 level. ** denotes significance at 0.05 level, ${ }^{* * *}$ denotes significance at 0.01 level,

Next, we examine how IHEs respond to the increase in applications received by utilizing the number of students admitted as the dependent variable in our analysis. Table 4 follows the design of Table 3, with two model specifications for each of our three DID samples. As with the results for applications, the signing of the ACUPCC is estimated to have a consistently positive and significant impact on admissions for a given institution. The magnitude of the impact on admissions is estimated to be larger than the impact on applications for both the signatory only and Green Guide samples, while it is slightly smaller when using the sample of all 4-year IHEs. The results here indicate that, as potential students respond to an institution's commitment to the environment by increasing applications, the institutions are responding by accepting more students. One explanation for this is that IHEs are willing and able to expand the number of students when they experience an increase in the number of applicants. Alternatively, it could be that IHEs face increasing competition for students and must admit more to yield the desired number of enrolled students.

Table 4: Regression results: admissions.

\begin{tabular}{|c|c|c|c|c|c|c|}
\hline & (1) & $\begin{array}{l}\text { (2) } \\
\text { guide }\end{array}$ & (3) & $\begin{array}{l}(4) \\
\text { tories }\end{array}$ & (5) & $\begin{array}{l}\text { (6) } \\
\text { Ir IHEs }\end{array}$ \\
\hline Signed & $\begin{array}{l}0.0361^{* *} \\
(0.0147)\end{array}$ & $\begin{array}{l}0.0327^{* *} \\
(0.0155)\end{array}$ & $\begin{array}{l}0.0334^{* *} \\
(0.0151)\end{array}$ & $\begin{array}{l}0.0374^{* *} \\
(0.0159)\end{array}$ & $\begin{array}{l}0.0263^{* *} \\
(0.0118)\end{array}$ & $\begin{array}{l}0.0279^{* *} \\
(0.0124)\end{array}$ \\
\hline $\begin{array}{l}\text { IHE-level } \\
\text { controls }\end{array}$ & No & Yes & No & Yes & No & Yes \\
\hline Observations & 3,648 & 3,377 & 4,205 & 3,854 & 12,353 & 11,216 \\
\hline$R$-squared & 0.988 & 0.988 & 0.985 & 0.985 & 0.981 & 0.982 \\
\hline
\end{tabular}

Notes: Table presents regression results from models in which dependent variable is In of admissions. Samples vary as described in text. Standard errors, clustered at IHE level, presented in parentheses. All specifications include IHE fixed effects, IHE-specific linear trends, and year fixed effects. IHE Level Controls are common application, HS graduates, income per capita, undergraduate application fee, lagged in-state tuition, lagged out-of-state tuition and lagged professor salary. All monetary variables measured in constant 2014 dollars. * * denotes significance at 0.10 level. $\quad * *$ denotes significance at 0.05 level, denotes significance at 0.01 level,

To this point we have consistent evidence across all three samples indicating that IHEs signing the ACUPCC agreement experience significant increases in applications received and students accepted for admission. The next logical question to consider is whether or not there will be an actual increase in enrollment at a given IHE as a result. To examine this, we follow the same format as the previous results, and utilize first-time enrollment in the fall of each year as the dependent variable in our various specifications. The results of these analyses are presented in Table 5. In this case, the estimated impact of signing is not consistently significant across our samples. The models using the Green Guide and signatory only samples show positive results at a moderate level of significance. The estimated magnitude of the impact on enrollment is smaller than that on applications and admissions. In the Green Guide sample, for instance, the point estimates for enrollment are almost exactly half the size of the estimated impacts on admissions displayed in Table 4. The sample of all 4-year IHEs yields insignificant results. 
Table 5: Regression results: enrollment.

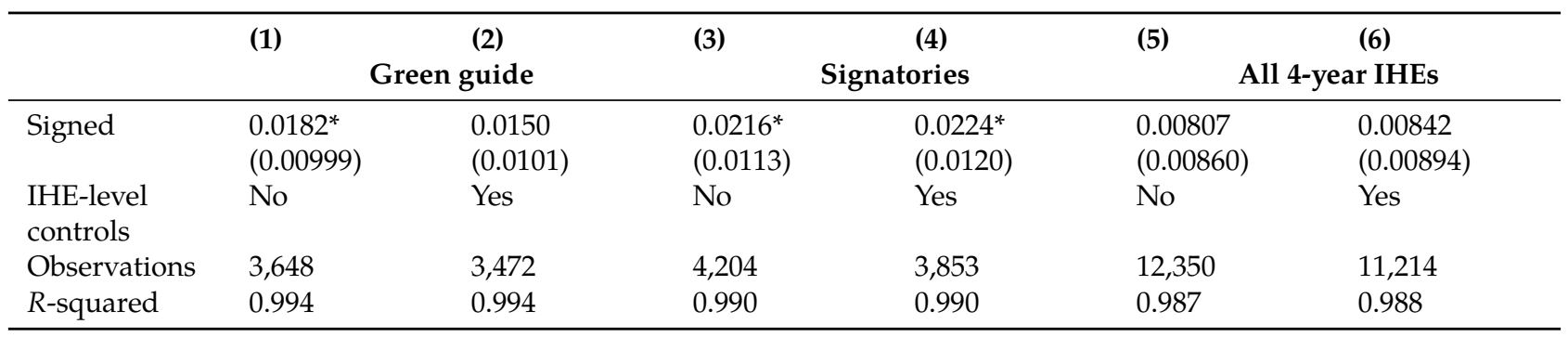

Notes: Table presents regression results from models in which dependent variable is In of first-time enrollments. Samples vary as described in text. Standard errors, clustered at IHE level, presented in parentheses. All specifications include IHE fixed effects, IHE-specific linear trends, and year fixed effects. IHE-level controls are common application, HS graduates, income per capita, undergraduate application fee, lagged in-state tuition, lagged out-of-state tuition and lagged professor salary. All monetary variables measured in constant 2014 dollars. * denotes significance at 0.10 level. $\quad * *$ denotes significance at 0.05 level,

*** denotes significance at 0.01 level,

Overall, there is some evidence of an impact on enrollments, but it is not as strong as the evidence of impacts on applications and admissions. One possible explanation for this is that the application process may be fairly low-cost and require little in the way of commitment from the consumer, particularly when compared to the enrollment decision. The signing of an environmental commitment may draw a potential student's interest and entice him or her to apply, but this factor alone may not be enough to impact the decision of where to ultimately enroll. Another potential explanation is that IHEs may not have the capacity (or desire) to actually enroll more students at a particular time. If this is true, and the ACUPCC signing does increase interest from consumers, then it is possible for the institution to respond in other ways. For example, the institution may choose to increase the quality of its student body, as opposed to the quantity, by being more selective. An increase in demand might also lead to a decision to increase the price of attending. To investigate these possible responses, we estimated the same set of models shown in Table 3, Table 4 and Table 5 using the average SAT score of the incoming class, the real rate of out-of-state tuition, and the admit rate (admissions/applications) as dependent variables. We did not find any evidence of statistical significance in these models. ${ }^{21}$ We explore this further in SubSection 4.2 where we look for heterogeneous IHE responses.

\subsection{Heterogeneity in the Results}

It is important to recognize that different types of IHEs may experience distinct responses to the signing of the ACUPCC. To begin exploring possible heterogeneity, we follow Pope and Pope (2009) in examining different impacts for private and public IHEs; these results are displayed in Table 6. To simplify this and all subsequent tables, we present only the results of the specifications with the full set of control variables and for all 4-year IHEs. $^{22}$ The estimated coefficients indicate that the increase in applications due to signing is primarily observed in private institutions; these differences are statistically significant. Note that this difference does not appear to be driven by differences in the frequency or timing of signing by sector; the descriptive information in Table 2 reveals strikingly similar patterns in the number of IHEs signing the ACUPCC agreement over time in each sector. One possible explanation for the differential impact across sectors is that the typical student interested in attending a private institution has a different set of preferences than the typical student applying to public sector schools. For example, the decision to apply to IHEs in the public sector may largely be driven by geographic location, given differentials in tuition between in-state and out-of-state students. The decision to apply to IHEs in the private sector, on the other hand, may be more likely to be influenced by the specific attributes offered. ${ }^{23}$ The results in Table 6 seem to indicate that a commitment to the environment may be one such attribute.

Table 6: Regression results: results by sector.

\begin{tabular}{|c|c|c|c|c|c|c|}
\hline & \multirow{2}{*}{\multicolumn{2}{|c|}{$\begin{array}{c}(2) \\
\text { Ln applications }\end{array}$}} & \multirow{2}{*}{\multicolumn{2}{|c|}{$\begin{array}{c}(4) \\
\text { Ln admissions }\end{array}$}} & \multirow{2}{*}{\multicolumn{2}{|c|}{$\begin{array}{c}\text { (6) } \\
\text { Ln enrollment }\end{array}$}} \\
\hline & & & & & & \\
\hline & Public & Private & Public & Private & Public & Private \\
\hline Signed & $\begin{array}{l}0.0150 \\
(0.0142)\end{array}$ & $\begin{array}{l}0.0411^{* *} \\
(0.0186)\end{array}$ & $\begin{array}{l}0.0201 \\
(0.0169)\end{array}$ & $\begin{array}{l}0.0367^{* *} \\
(0.0177)\end{array}$ & $\begin{array}{l}-0.00279 \\
(0.0119)\end{array}$ & $\begin{array}{l}0.0165 \\
(0.0133)\end{array}$ \\
\hline Observations & 4,325 & 6,891 & 4,325 & 6,891 & 4,325 & 6,889 \\
\hline$R$-squared & 0.988 & 0.983 & 0.982 & 0.975 & 0.986 & 0.977 \\
\hline
\end{tabular}


Notes: Table presents regression results from sample of all 4-year IHEs. Columns in this table represent results when further restricting samples based on sector of institution. Standard errors, clustered at IHE level, presented in parentheses. All specifications include IHE fixed effects, IHE-specific linear trends, year fixed effects, common application, HS graduates, income per capita, undergraduate application fee, lagged in-state tuition, lagged out-of-state tuition (public only) and lagged professor salary. All monetary variables measured in constant 2014 dollars. * denotes significance at 0.10 level. ** denotes significance at o.05 level, $\quad$ *** denotes significance at 0.01 level,

When we examine the impact on admissions by sector, displayed in columns 3 and 4 of Table 6, we again see that the significant increases as a result of signing seem to be limited to IHEs in the private not-for-profit sector. In columns 5 and 6 of Table 6, we proceed to estimate the impacts on enrollment by sector of institution. As with both applications and admissions, the point estimate is larger for private institutions. However, the coefficients are not statistically significant.

Furthermore, the IHE response to an increase in student interest may depend upon the position of the IHE. For example, more selective IHEs may be more likely to be meeting their enrollment targets whereas less selective IHEs may not be doing so. Thus, we may not expect to see as much of an increase in admissions or enrollment at more selective IHEs compared to less selective IHEs. To investigate this issue, we divide our sample by the average admit rate in the years prior to 2007. We classify IHEs with average admit rates below the median as more selective and IHEs with average admit rates above the median as less selective. We then estimate 2 on these subsamples for the outcomes of (logged) applications, admissions, and enrollment. These results are displayed in Table 7. Point estimates for the effect of signing on applications are positive for both subgroups, but only statistically significant for less selective IHEs. The point estimate is also more than twice as large for less selective IHEs compared to more selective IHEs. A possible reason for this difference is that students trying for more selective IHEs may be primarily focused on academic attributes whereas students applying to less selective IHEs may be relatively more concerned with other non-academic factors such as the ACUPCC. However, one would likely require student level data to test this explanation. A similar pattern holds in columns 3 and 4 of Table 7, for the impact of signing on admissions. Finally, as theorized, we find evidence of an increase in enrollment due to signing only for less selective IHEs. We find essentially no impact of signing on enrollment for more selective IHEs. We then tested for impacts on admit rates and the SAT score of the incoming class to see if more selective IHEs capitalize on increased student interest by becoming even more selective. Coefficients in these regressions are near 0 and not statistically significant. ${ }^{24}$

Table 7: Regression results: results by selectivity.

\begin{tabular}{|c|c|c|c|c|c|c|}
\hline & \multirow[t]{2}{*}{ (1) } & (2) & \multirow{2}{*}{\multicolumn{2}{|c|}{$\begin{array}{c}(4) \\
\text { Ln Admissions }\end{array}$}} & \multirow{2}{*}{\multicolumn{2}{|c|}{$\begin{array}{c}(6) \\
\text { Ln Enrollment }\end{array}$}} \\
\hline & & cations & & & & \\
\hline & $\begin{array}{l}\text { More } \\
\text { Selective }\end{array}$ & Less Selective & $\begin{array}{l}\text { More } \\
\text { Selective }\end{array}$ & Less Selective & $\begin{array}{l}\text { More } \\
\text { Selective }\end{array}$ & Less Selective \\
\hline Signed & $\begin{array}{l}0.0210 \\
(0.0163)\end{array}$ & $\begin{array}{l}0.0473^{* * * *} \\
(0.0181)\end{array}$ & $\begin{array}{l}0.0159 \\
(0.0168)\end{array}$ & $\begin{array}{l}0.0418^{* *} \\
(0.0186)\end{array}$ & $\begin{array}{l}-0.00656 \\
(0.0130)\end{array}$ & $\begin{array}{l}0.0282^{* *} \\
(0.0125)\end{array}$ \\
\hline Observations & 5,419 & 5,797 & 5,419 & 5,797 & 5,418 & 5,796 \\
\hline$R$-squared & 0.987 & 0.984 & 0.980 & 0.984 & 0.987 & 0.988 \\
\hline
\end{tabular}

Notes: Table presents regression results from sample of all 4-year IHEs. Columns in this table represent results when further restricting samples based on IHE selectivity. Standard errors, clustered at IHE level, presented in parentheses. All specifications include IHE fixed effects, IHE-specific linear trends, year fixed effects, common application, HS graduates, income per capita, undergraduate application fee, lagged in-state tuition, lagged out-of-state tuition and lagged professor salary. * denotes significance at 0.10 level. ** denotes significance at 0.05 level, $\quad * * *$ denotes significance at 0.01 level,

\section{Alternative Specifications and Robustness Checks}

\subsection{Robustness of the DID Application Results}

We investigate the robustness of our DID estimates regarding the impact of signing the ACUPCC on applications in a few ways. First, we investigate the use of IHE-specific quadratic time trends. The analyses in Table 3, Table 4, Table 5, Table 6, Table 7 include linear time trends, but it is possible that a more flexible functional form better captures IHE-specific trends. Column 1 of Table 8 shows the results when estimating the model with logged applications as the dependent variable and including IHE-specific quadratic time trends. The results are similar to those observed in the analogous column 6 of Table $3 .^{25}$ The second robustness check involves the assignment of ACUPCC signing to a specific year where we expect an impact on applications. Our primary analysis assumes IHEs signing in the first half of the year will see an impact (if one exists) in the fall of that year. Those signing in the second half of the year will see a potential impact the following year. We estimate the 
models using logged applications as the dependent variable, and shift the cutoff to assignment one month in each direction. ${ }^{26}$ Columns 2 and 3 of Table 8 display the results for this robustness check; the estimated effect does not seem sensitive to our choice of the month cutoff.

Table 8: Regression results: robustness checks.

\begin{tabular}{|c|c|c|c|c|c|c|c|}
\hline & $\begin{array}{l}\text { (1) } \\
\text { Quadratic } \\
\text { trends }\end{array}$ & $\begin{array}{l}\text { (2) } \\
\text { May cutoff }\end{array}$ & $\begin{array}{l}\text { (3) } \\
\text { July cutoff }\end{array}$ & $\begin{array}{l}(4) \\
\text { Excluding } \\
2007\end{array}$ & $\begin{array}{l}\text { (5) } \\
\text { Additional } \\
\text { IHE } \\
\text { controls }\end{array}$ & $\begin{array}{l}\text { (6) } \\
\text { Adding } \\
\text { SAT }\end{array}$ & $\begin{array}{l}\text { (7) } \\
\text { Timing of } \\
\text { effects }\end{array}$ \\
\hline Signed & $\begin{array}{l}0.0242^{* *} \\
(0.0118)\end{array}$ & $\begin{array}{l}0.0273^{* *} \\
(0.0114)\end{array}$ & $\begin{array}{l}0.0282^{* *} \\
(0.0120)\end{array}$ & $\begin{array}{l}0.0427^{* * *} \\
(0.0148)\end{array}$ & $\begin{array}{l}0.0313^{* * *} \\
(0.0120)\end{array}$ & $\begin{array}{l}0.0242^{* *} \\
(0.0121)\end{array}$ & \\
\hline $\begin{array}{l}\text { Immedi- } \\
\text { ately } \\
\text { after }\end{array}$ & & & & & & & $0.0285^{* *}$ \\
\hline 1 year after & & & & & & & $\begin{array}{l}(0.0112) \\
0.0204 \\
(0.0152)\end{array}$ \\
\hline 2 years after & & & & & & & $\begin{array}{l}0.0195 \\
(0.0194)\end{array}$ \\
\hline 3 years after & & & & & & & $\begin{array}{l}0.0101 \\
(0.0233)\end{array}$ \\
\hline $\begin{array}{l}\geq 4 \text { years } \\
\text { after }\end{array}$ & & & & & & & 0.000637 \\
\hline $\begin{array}{l}\text { Observa- } \\
\text { tions }\end{array}$ & 11,216 & 11,216 & 11,216 & 10,235 & 10,430 & 8,408 & $\begin{array}{l}(0.0285) \\
11,216\end{array}$ \\
\hline$R$-squared & 0.991 & 0.987 & 0.987 & 0.987 & 0.988 & 0.989 & 0.987 \\
\hline
\end{tabular}

\subsection{Alternative Explanations and Falsification Tests}

A leading concern for our identification is that the signing of the ACUPCC could have coincided with other changes at the IHE level. If any such changes led to an increase in student interest and applications, we could be misattributing this onto the ACUPCC signing. This will not cause problems for identification in the DID approach if any such changes are common between signatories and non-signatories. If however, any such changes are unique to signatories, it could be cause for concern. We can never completely rule out this possibility because there are many unobservable factors that could have changed only for signatories at the time of signing. However, we take several approaches to assuage this concern.

First, it is clear from Table 2 that the single largest effective signing year was 2007. Perhaps there was something special happening during this year, common to signatories, that also affected student interest. Therefore, we exclude all observations from 2007 and re-estimate 2. As seen in column 4 of Table 8, the estimated effect of signing on applications actually grows in magnitude and is significant at the $1 \%$ level.

Next, we expand our list of time-varying IHE controls beyond what is included in Table 3. We add the following one year lags of student demographics: percent female, percent Asian, percent Indian, percent Hispanic, percent Black, and percent non-resident alien. These demographics thus represent the average characteristics of the IHE student body at the time of application. We also add an indicator to characterize whether or not an IHE hired a new president effective for the current year. The rationale here is that a new president may change many unobservable things at an IHE while simultaneously signing the ACUPCC. As shown in column 5 of Table 8, these additional time-varying controls do not change the results. We then add in the average SAT score while retaining the controls from column 5 and report these results in column 6 of Table 8. Although the sample size is considerably smaller when including SAT, the coefficient on signing the ACUPCC remains of similar magnitude and significant at the $5 \%$ level.

Another issue is the timing of the effects. For instance, there could be an immediate jump in applications after signing that ultimately declines or there could be a delay in prospective students becoming aware of and responding to the signing. To investigate this issue, we return to 2 and replace the indicator, $S_{i t}$, with a set 
of indicators representing the number of years that have passed since signing. We create indicators for the immediate effect, and for 1, 2, 3, and 4 or more years after the ACUPCC signing. The coefficients on these indicators are then interpreted as relative to the omitted category of the pre-signing years. Column 7 of Table 8 shows that the immediate effect is the largest and the only effect that is separately statistically significant at conventional levels. ${ }^{27}$ Also, there appear to be smaller but still positive effects on applications 1 to 3 years after signing. However, it also seems that the effects dissipate and may eventually disappear after 4 years have passed. This motivates a falsification test regarding moving the timing of signing. We move the actual signing date 2 years into the future to create a falsified signing date. Given, the pattern in column 6 of Table 8, it would be problematic to still find significant impacts of signing with this falsified signing date. Note that, with the falsified signing date, the first 2 years of actual effects from signing would be treated as occurring during the pre-signing period. Column 1 of Table 9 shows that we find no effect on applications when using this 2 year delayed false signing date. ${ }^{28}$

Table 9: Regression results: falsification tests.

\begin{tabular}{llllll}
\hline & $\mathbf{( 1 )}$ & $\mathbf{( 2 )}$ & $\mathbf{( 3 )}$ & $\mathbf{( 4 )}$ & $\mathbf{( 5 )}$ \\
& $\begin{array}{l}\text { Delay 2 years } \\
\text { (applications) }\end{array}$ & $\begin{array}{l}\text { Instructional } \\
\text { expenditures }\end{array}$ & $\begin{array}{l}\text { Academic } \\
\text { support }\end{array}$ & $\begin{array}{l}\text { Student services } \\
\text { Auxiliary } \\
\text { enterprises }\end{array}$ \\
\hline Signed & -0.00966 & -0.00322 & -0.0163 & -0.00875 & 0.00199 \\
& $(0.0121)$ & $(0.0198)$ & $(0.0217)$ & $(0.0213)$ & $(0.0226)$ \\
Observations & 11,216 & 10,009 & 9,980 & 10,003 & 9,949 \\
R-squared & 0.987 & 0.995 & 0.990 & 0.983 & 0.984 \\
\hline
\end{tabular}

Notes: Table presents regression results from sample of all 4-year IHEs and models in which dependent variable is logged. Standard errors, clustered at IHE level, presented in parentheses. All specifications include IHE fixed effects, IHE-specific linear trends, year fixed effects, common application, HS graduates, income per capita, undergraduate application fee, lagged in-state tuition, lagged out-of-state tuition and lagged professor salary. * denotes significance at 0.10 level. $\quad{ }^{* *}$ denotes significance at 0.05 level, $\quad{ }^{* * *}$ denotes significance at 0.01 level,

Finally, we implement a series of falsification tests to look for changes in observable IHE characteristics that may coincide with signing the ACUPCC. As discussed, we cannot control for every possible confounding variable, but we can look at a series of key expenditure variables available in IPEDS data. This allows us to determine whether there seems to be a shift in IHE administration or policy of which signing the ACUPCC is just one part. We return to equation 2 and replace the outcome variable with expenditures, separately, for each of the following categories: instructional, academic support, student services, and auxiliary enterprises. ${ }^{29}$ We choose these categories because these are the ones that are likely to influence student recruitment. If we find a significant coefficient for our ACUPCC signing variable, it might indicate that the signing was indeed coinciding with other factors driving our findings regarding applications, admissions, and enrollments. As evidenced by the results in columns 2 through 5 of Table 9, we do not find any significance that would justify this particular concern.

\subsection{Interrupted Time Series}

As a final robustness check, we estimate an interrupted time series model, which allows the pre-signing and post-signing trends to differ. ${ }^{30}$ Prior to presenting the regression results, we first provide some graphical evidence of a discontinuity in applications at the effective signing year. We do the following in Figure 1 to show the discontinuity for logged applications. ${ }^{31}$

(1) Take the natural log of applications.

(2) Demean logged applications for each IHE.

(3) Plot average demeaned applications across sample IHEs versus $\hat{T}_{i t} .{ }^{32}$

(4) Draw a line of best fit for average demeaned applications on each side of the effective signing year. 


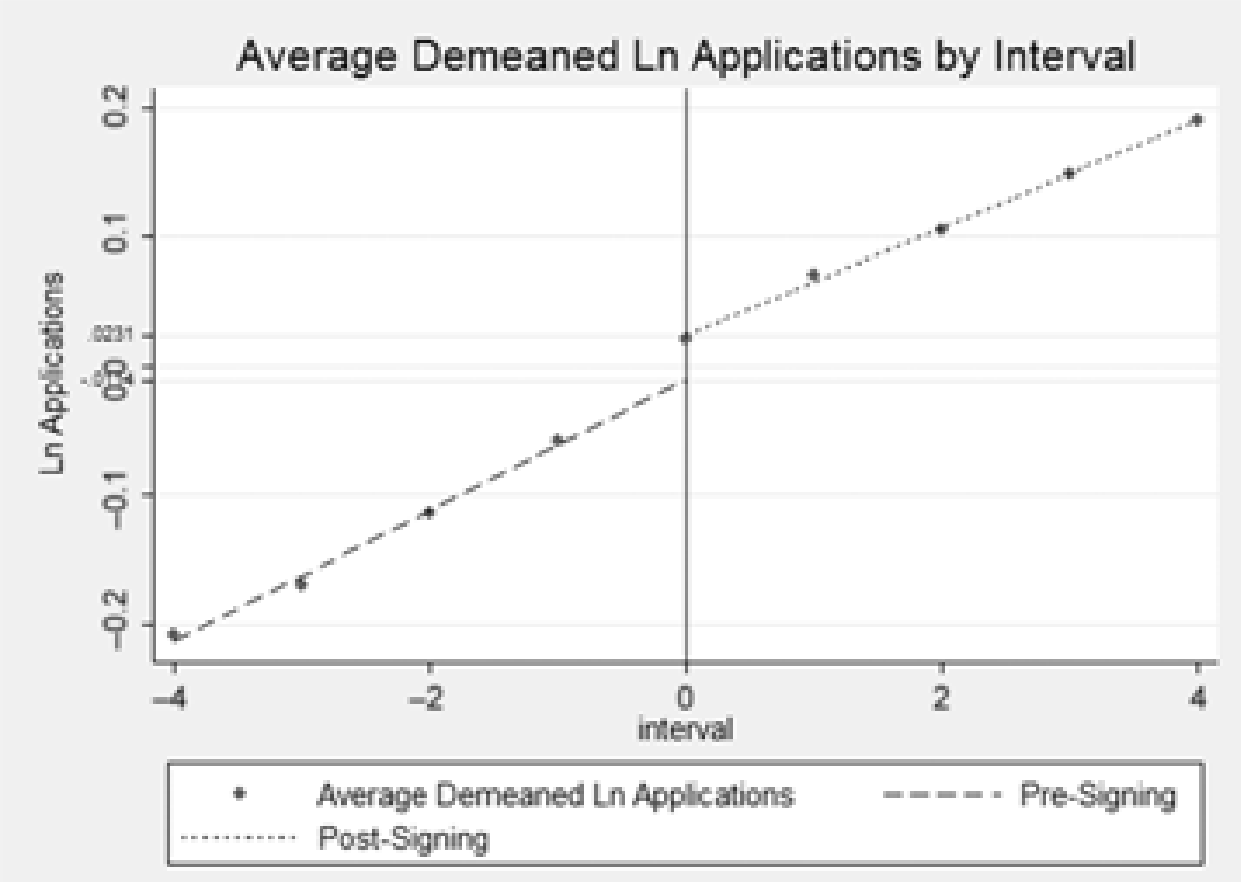

Figure 1: Applications relative to ACUPCC effective signing date.

The difference in the intercepts of the lines of best fit at $\hat{T}_{i t}=0$ gives us an idea of the magnitude of the discontinuity. This is $0.0231-(-0.0114)=0.0345$. Thus, on average, applications increase by about $3.5 \%$ at the effective signing year according to this graphical evidence. We also note that the trends of logged applications in both the pre-signing period and in the post-signing appear linear.

Table 10 presents the results of our interrupted time series analysis using both linear and quadratic controls. For both linear and quadratic specifications, the results indicate that signing has a positive and significant impact on applications. ${ }^{33}$ As with the results in the previous section, we find that the signal of environmental commitment provided by the ACUPCC has a substantial impact on the number of potential students that decide to apply. ${ }^{34}$ We also look for discontinuities in other factors that could explain the change in applications simultaneously with the signing of the ACUPCC. Specifically, we estimate eq. 4 for the dependent variables of real application fee, ${ }^{35}$ logged real application fee, logged real out-of-state tuition, and percentage of tenuretrack faculty ${ }^{36}$ and find no evidence of discontinuities. As seen in Appendix Table 13, estimated coefficients are near 0 , with relatively large standard errors. This provides further evidence to solidify our claim that changes in applications and other outcome variables are driven by potential students responding to the signing of the ACUPCC, rather than simultaneous changes in other factors.

Table 10: Interrupted time series results: bandwidth of 4 years.

\begin{tabular}{lllllll}
\hline & $\mathbf{( 1 )}$ & $\begin{array}{c}(\mathbf{2}) \\
\text { Applications }\end{array}$ & $\mathbf{( 3 )}$ & $\begin{array}{c}\mathbf{( 4 )} \\
\text { Admissions }\end{array}$ & $\mathbf{( 5 )}$ & \multicolumn{2}{c}{ (6) } \\
& Linear & Quadratic & Linear & Quadratic & Linear & Quadratic \\
\hline Signed & $0.0367^{* * *}$ & $0.0311^{*}$ & $0.0403^{* *}$ & 0.0145 & 0.00619 & 0.00839 \\
& $(0.0136)$ & $(0.0174)$ & $(0.0162)$ & $(0.0247)$ & $(0.0115)$ & $(0.0227)$ \\
Observations & 2,727 & 2,727 & 2,727 & 2,727 & 2,726 & 2,726 \\
$R$-squared & 0.487 & 0.487 & 0.346 & 0.346 & 0.118 & 0.118 \\
Number of & 319 & 319 & 319 & 319 & 319 & 319 \\
IHEs & & & & & & \\
\hline
\end{tabular}

Notes: Table presents result from interrupted time series models. The bandwidth of 4 years in these models means we include IHEs signing in 2009 or earlier. Standard errors, clustered at IHE level, presented in parentheses. Dependent variables in each regression are in natural logarithmic form. Each regression includes year and IHE fixed effects. * denotes significance at 0.10 level. $\quad * *$ denotes significance at 0.05 level, $\quad * * *$ denotes significance at 0.01 level, 


\section{Conclusion}

The eco-labeling of products is increasingly used as a way for firms to send a signal to consumers about the firm's level of commitment to the environment, and is a leading example of a VIBA. To this point, however, little empirical research has investigated how successful VIBAs have been in impacting consumer behavior. This is especially true when it comes to the case of the eco-labeling of services. In this study, we analyze the student response to the American College and University Presidents' Climate Commitment, an eco-label in higher education.

In this case, the primary response that we investigate is whether or not the decision to apply to a particular institution is influenced by the institution's signing of this agreement. Using both difference-in-difference and interrupted time-series strategies, we find consistent evidence of a significant positive response in the number of applications received after signing the agreement. We also find evidence that the IHEs respond to this increase in interest from students by significantly increasing the number of students they admit. However, we find weaker evidence regarding the impact of the eco-label on the ultimate decision of whether or not to enroll in a particular IHE. Higher education is an example of a costly service with many attributes; thus we may expect the IHE's green commitment to not be as influential in the enrollment decision. In contrast, the marginal cost of sending an application is rather low so students may be willing to act on environmental information. In relation to the theory of green clubs, evidence does firmly suggest that the club increases the visibility of member IHEs. However, it is less clear that this increased visibility translates into changes in individuals' costly decisions.

The strongest enrollment effects are concentrated in less selective IHEs. One explanation is that these same institutions may not have as firm of a capacity constraint compared to more selective IHEs - which likely receive plenty of applications to reach enrollment targets. Another possible explanation is that a green commitment may simply not be as important to students as other factors when choosing among more selective IHEs but an effective differentiator for less selective IHEs. Data at the prospective student level could help determine the ultimate reasons for the heterogeneous enrollment impacts.

There are two important dimensions to consider when assessing the potential of VIBAs to be effective environmental management programs. The first dimension, environmental effectiveness, has received somewhat more attention. There, results are mixed as to whether or not VIBAs generate significant public benefits. Regardless of the extent of public benefits, however, we would not expect specific VIBAs to survive if they do not generate sufficient private benefits to offset the private cost of their adoption. Our results show that VIBAs can be effective along this dimension in at least generating more attention for the service. However, the open question is under what circumstances this extra attention then translates into more lasting changes in consumer behavior.

\section{Notes}

${ }^{1}$ We are aware of only one working paper in this area. Sipic (2010) finds a substantial price premium for the Blue Flag label for marinas and beaches within a hedonic framework. The author utilizes instrumental variables to address the endogeneity of certification in the cross-sectional analysis.

${ }^{2}$ As of October 2015, the ACUPCC has been renamed the "Carbon Commitment." Second Nature now also offers IHEs the ability to sign additional commitments to climate resilience. This change has no bearing on the study at hand because it occurred after our sample period.

${ }^{3}$ For example, according to Princeton Review's 2014 "College Hopes and Worries Survey," 62\% of college applicants say that having information about an IHE's commitment to environmental issues would impact their decision to apply to a school.

${ }^{4}$ An entire literature has been devoted to explaining why individuals voluntarily contribute to public goods.

${ }^{5}$ There are many papers in the finance literature that examine the effect of environmental performance (often referred to as Corporate Social Responsibility) on firm financials. The results there are mixed; for reviews of these studies see Graff Zivin and Small (2005), McWilliams and Siegel (2000), and Stefan and Paul (2008) .

${ }^{6}$ Alberini and Segerson (2002) provide an excellent analysis of the earlier theoretical and empirical literature related to VIBAs.

${ }^{7}$ We are grateful to Second Nature for providing us with the ACUPCC data in spreadsheet format.

${ }^{8}$ While all institutions participating in federal financial aid programs are required to complete IPEDS surveys, not all surveys are required from all types of institutions every year, and not all information on a given survey will be completed by each IHE in each year. As a result, the number of IHEs for which information is available depends on the variables used in our analysis, and the number of observations will vary with each model specification.

${ }^{9}$ In any given survey year, some IHEs report information on applications in the current year, and some report for the previous year. In order to include the most recent information, we include data for the IHEs that have reported for the 2013-14 academic year, despite the fact that not all institutions have reported.

${ }^{10}$ We also gather SAT information where it is available. We sum the average of the $25^{\text {th }}$ and $75^{\text {th }}$ percentiles of math and verbal scores for incoming first-year students. These scores are missing for over $25 \%$ of our observations but we include it as a robustness check in Section 5.

${ }^{11}$ We obtain this information directly from the Common Application (www.commonapp.org). 
${ }^{12} \mathrm{As}$ examples, we found articles in local media (http://www.startribune.com/several-colleges-push-for-eco-friendlycampuses/124808624/), on IHE websites (http://www.pugetsound.edu/news-and-events/campus-news/details/245/), and in more general environmental news sources (http:/ /www.environmentalleader.com/2013/04/08/colby-college-achieves-carbon-neutrality/)

${ }^{13}$ This corresponds to the 2000 Carnegie Classifications of 15-32, sectors 1-2.

${ }^{14}$ We conduct some robustness tests on this assumption in Section 5.

${ }^{15}$ Leaving out observations prior to 2006 does not substantially change results. Point estimates and $p$-values change only slightly and are available upon request.

${ }^{16}$ The complete guide we used to construct our sample can be found online at http://www.princetonreview.com/collegerankings/green-guide?rankings=green-colleges. This guide lists 353 IHEs the Princeton Review determined to be "...those with the highest Green Ratings, featuring green initiatives that enhance students' academic experience and quality of life in ways that truly merit recognition." Green Rating scores are determined based on surveys regarding institutional policies. The guide presents these IHEs in alphabetical order without numerical ranking (or specific Green Rating), though those in the top 50 of Green Rating scores are highlighted.

${ }^{17}$ Note that the variation in timing of signing is important here because, if all signatories had signed at the same time, any effects on the outcome variables would be subsumed into the year fixed-effects.

${ }^{18}$ For the "signatories only" sample, we test for differences between those that signed in 2007 and those that signed later. A little under half of those that sign do so in 2007.

${ }^{19}$ In addition to reducing sample size, the primary reason for not including these variables in all specifications is that there is also a potential endogeneity issue. For example, it is possible that cost of attendance is decided, in part, based on the number of applicants a school expects to receive. Because of this, we present results with and without these controls, and lag the total cost of attendance and average professor salary variables by one year. We also estimated the simple specification using the restricted sample size that results from including the control variables. The significance and magnitude did not change in any meaningful way when the sample size is restricted. The results of these specifications (as well as the analogous results for admissions and enrollment) are available upon request.

${ }^{20} \mathrm{To}$ give a sense of the magnitude of the results, we present the results of our main specifications using the level of applications, admissions, and enrollment (rather than the logged values) in Appendix Table 12. The results are less statistically significant when estimating in levels, with the coefficient on signing not significantly impacting admissions at conventional levels. The signing of ACUPCC is estimated to increase the number of applications, all else equal, by around 187.

${ }^{21}$ The results of these analyses are available upon request.

${ }^{22}$ The results do not vary substantially in either magnitude or significance of the estimated coefficients when examining the simple specification without controls for each of the models, or when limiting the sample to green guide or signatory comparison groups. Full results are available upon request.

${ }^{23}$ One piece of evidence that supports this theory can be found by comparing the coefficients on the state-level control variables. Applications to public IHEs are significantly positively influenced by income and the number of high school graduates in the state, whereas applications to private institutions have no statistical relationship with these state-level controls.

${ }^{24}$ These results are available upon request.

${ }^{25}$ We also estimate the quadratic trends models with admissions and enrollment as the dependent variables, and obtain results qualitatively similar to those in Table 4 and Table 5, respectively.

${ }^{26}$ To clarify, the standard cutoff we use to assign signing to year of impact on applications is the end of June. In this specification we change the cutoff to the end of May and the end of July in separate models.

${ }^{27}$ We also estimated the same model adding an interaction between indicators for signing during the fall application season (Aug.-Dec.) and being in the year immediately following signing. The point estimate on the coefficient of the interaction term is -0.00897 with a $p$-value of 0.608 so we do not find any evidence that the season of signing matters.

${ }^{28}$ We also do the same estimation when moving the signing date 1 year into the future. The estimated coefficient on "signed" is 0.00354 and insignificant with a standard error of 0.0119 .

${ }^{29}$ The IPEDS website lists the description of this category as operating expenditures related to operations in the IHE that are generally self-supporting, such as residence halls and student health services.

${ }^{30}$ We provide the details of this empirical model in the appendix.

${ }^{31}$ We also created analogous figures for the outcomes of admissions and enrollment but omit them here. The admissions graph shows a similar discontinuity whereas the enrollment graph shows a change in slope but no visible discontinuity at the signing date. These figures are available upon request.

${ }^{32}$ Note that this is equivalent to plotting the average residuals from the regression of the logged outcome on a set of IHE fixed-effects.

${ }^{33}$ We also estimated with a bandwidth of 3 years, instead of 4 . As an additional robustness check, we limited our sample to those IHEs that created a balanced panel using a bandwidth of 4 years. The significance levels and general conclusions are similar to those found in Table 10. These tables are available upon request.

${ }^{34}$ For the admissions variable, we find a significant positive impact of signing using linear controls, but no significant impact when including quadratic controls. We find no evidence of a significant impact on enrollment in either specification.

${ }^{35}$ We include the level of real application fee in addition to logged real application fee because there are some IHEs with $\$ 0$ application fees. These schools are dropped in the logged analysis.

${ }^{36}$ Many IHE observable characteristics relating to the student profile such as average SAT score are likely impacted by the pool of applicants received by the IHE and hence impacted by the signing of the ACUPCC. Thus, we choose IHE characteristics relating to the faculty as a plausibly exogenous factors that should not display discontinuities.

\section{References}

Alberini, A., and K. Segerson. 2002. "Assessing Voluntary Programs to Improve Environmental Quality." Environmental and Resource Economics 22 (1-2): 157-184.

Alter, M., and R. Reback. 2014. "True for Your School? How Changing Reputations Alter Demand for Selective US Colleges." Educational Evaluation and Policy Analysis 36 (3): 346-370.

ACUPCC Mission and History. Second Nature, [Online] 2014 http://www.presidentsclimatecommitment.org/about/mission-history.

Angrist, J. D., and A. B. Krueger. 1999. "Empirical Strategies in Labor Economics." Handbook of Labor Economics 3 : 1277-1366. 
Arora, S., and T. N. Cason. 1996. "Why Do Firms Volunteer to Exceed Environmental Regulations? Understanding Participation in EPA's $33 / 50$ Program." Land Economics 72 (4): 413-432.

Arora, S., and T. N. Cason. 1995. "An Experiment in Voluntary Environmental Regulation: Participation in EPA's 33/50 Program." Journal of Environmental Economics and Management 28 (3): 271-286.

Arora, S., and S. Gangopadhyay. 1995. "Toward a Theoretical Model of Voluntary Overcompliance." Journal of Economic Behavior $\&$ Organization 28 (3): 289-309.

Bagnoli, M.,, and S. G. Watts. 2003. "Selling to Socially Responsible Consumers: Competition and The Private Provision of Public Coods." Journal of Economics \& Management Strategy 12 (3): 419-445.

Baron, D. P 2007. "Corporate Social Responsibility and Social Entrepreneurship." Journal of Economics \& Management Strategy 16 (3): $683-717$.

Besley, T., and M. Ghatak. 2007. "Retailing Public Goods: The Economics of Corporate Social Responsibility." Journal of Public Economics 91 (9): $1645-1663$.

Bjorner, T. B., L. G. Hansen,, and C. S. Russell. 2004. “Environmental Labeling and Consumers' Choice-An Empirical Analysis of the Effect of the Nordic Swan." Journal of Environmental Economics and Management 47 (3): 411-434.

Brounen, D., and N. Kok. 2011. "On the Economics of Energy Labels in the Housing Market." Journal of Environmental Economics and Management 62 (2): 166-179.

College Hopes and Worries Results. The Princeton Review, [Online] 2014 http://www.princetonreview.com/college-hopes-worries.aspx.

Curs, B., and L. D. Singell. 2002. "An Analysis of the Application and Enrollment Processes for In-state and Out-of-state Students at a Large Public University." Economics of Education Review 21 (2): 111-124.

Deng, Y., Z. Li, and J. M. Quigley. 2012. "Economic Returns to Energy-Efficient Investments in the Housing Market: Evidence from Singapore." Regional Science and Urban Economics 42 (3): 506-515.

Des]ardins, S. L., D. A. Ahlburg, and B. P. McCall. 2006. "An Integrated Model of Application, Admission, Enrollment, and Financial Aid." Journal of Higher Education 77 (3): 381-429.

Dynarski, S. M 2003. "Does Aid Matter? Measuring the Effect of Student Aid on College Attendance and Completion." American Economic Review 93 (1): 279-288.

Eichholtz, P., N. Kok, and J. M. Quigley. 2013. "The Economics of Green Building." Review of Economics and Statistics 95 (1): $50-63$.

Eichholtz, P., N. Kok, and J. M. Quigley. 2010. "Doing Well by Doing Good? Green Office Buildings." The American Economic Review 100 (5): 2492-2509.

Fuerst, F., and P. McAllister. 2011a. "Eco-Labeling in Commercial Office Markets: Do LEED and Energy Star Offices Obtain Multiple Premiums?" Ecological Economics 70 (6): 1220-1230.

Fuerst, F., and P. McAllister. 2011b. "Green Noise or Green Value? Measuring the Effects of Environmental Certification on Office Values." Real Estate Economics 39 (1): 45-69.

Camper-Rabindran, S. 2006. "Did the EPA's Voluntary Industrial Toxics Program Reduce Emissions? A CIS Analysis of Distributional Impacts and By-Media Analysis of Substitution." Journal of Environmental Economics and Management 52 (1): 391-410.

Graff Zivin, J., and A. Small. 2005. "A Modigliani-Miller Theory of Altruistic Corporate Social Responsibility." B.E. Journal of Economic Analysis and Policy: Topics in Economic Analysis and Policy 5 (1): 1-19.

Heller, D. E 1999. "The Effects of Tuition and State Financial Aid on Public College Enrollment." The Review of Higher Education 23 (1): 65-89.

Imbens, G. W., and J. M. Wooldridge. 2009. "Recent Developments in the Econometrics of Program Evaluation." Journal of Economic Literature 47 (1): 5-86

Jacob, B., B. McCall, and K. M. Stange. (2013).NBER Working Paper No. w18745 College as Country Club: Do Colleges Cater to Students' Preferences for ConsumptionNational Bureau of Economic Research.

Kennedy, P. W., B. Laplante, and J. Maxwell. 1994. "Pollution Policy: The Role for Publicly Provided Information." Journal of Environmental Economics and Management 26 (1): 31-43.

Khanna, M., and L. A. Damon. 1999. "EPA's Voluntary 33/50 Program: Impact on Toxic Releases and Economic Performance of Firms." Journal of Environmental Economics and Management 37 (1): 1-25.

King, A. A., and M. J. Lenox. 2000. "Industry Self-Regulation without Sanctions: The Chemical Industry's Responsible Care Program." Academy of Management Journal 43 (4): 698-716.

Kotchen, M. ] 2013. "Voluntary- and Information-Based Approaches to Environmental Management: A Public Economics Perspective." Review of Environmental Economics and Policy 7 (2): 276-295.

Liu, A. Y. H., R. G. Ehrenberg, and J. Mrdjenovic. (2007).NBER Working Paper No. 13175 Diffusion of Common Application Membership and Admissions Outcomes at American Colleges and UniversitiesNational Bureau of Economic Research.

Loureiro, M. L., and ]. Lotade. 2005. "Do Fair Trade and Eco-Labels in Coffee Wake up the Consumer Conscience?" Ecological Economics 53 (1): 129-138.

Loureiro, M. L., J. J. McCluskey, and R. C. Mittelhammer. 2001. "Assessing Consumer Preferences for Organic, Eco-labeled, and Regular Apples." Journal of Agricultural and Resource Economics 26 (2): 404-416.

Luca, M., and J. Smith. 2013. "Salience in Quality Disclosure: Evidence from the US News College Rankings." Journal of Economics \& Management Strategy 22 (1): 58-77.

Lyon, T. P., and J. W. Maxwell. 2002. "Voluntary" Approaches to Environmental Regulation. Aldershot and Burlington, VT: Ashgate.

Lyon, T. P., and ]. W. Maxwell. 2003. "Self-Regulation, Taxation and Public Voluntary Environmental Agreements." Journal of Public Economics 87 (7-8): 1453-1486.

Maxwell, J. W., T. P. Lyon, and S. C. Hackett. 2000. "Self-Regulation and Social Welfare: The Political Economy of Corporate Environmentalism." Journal of Law and Economics 43 (2): 583-617.

McWilliams, A., and D. Siegel. 2000. “Corporate Social Responsibility and Financial Performance: Correlation or Misspecification?" Strategic Management Journal 21 (5): 603-609.

Morgenstern, R. D., and W. A. Pizer. 2007. Introduction: The Challenge of Evaluating Voluntary Programs. Washington, DC: Resources for the Future. 
Morgenstern, R. D., W. A. Pizer, and J. Shih. 2007. Evaluating Voluntary U.S. Climate Programs: The Case of Climate Wise. Washington, DC: Resources for the Future.

Neill, C. 2009. "Tuition Fees and the Demand for University Places." Economics of Education Review 28 (5): 561-570.

Nimon, W., and J. Beghin. 1999. "Are Eco-Labels Valuable? Evidence from the Apparel Industry." American Journal of Agricultural Economics 81 (4): 801-811.

Petrakis, E., E. S. Sartzetakis, and A. Xepapadeas. 2005. "Environmental Information Provision as a Public Policy Instrument." B.E. Journal of Economic Analysis and Policy: Contributions to Economic Analysis and Policy 4 (1): 1-31.

Podhorsky, A. (2008). Working PapersYork University, Department of Economics A Survey of Environmental Labeling.

Pope, D. G., and J. C. Pope. 2009. "The Impact of College Sports Success on the Quantity and Quality of Student Applications." Southern Economic Journal 75 (3): 750-780.

Potoski, M., and A. Prakash. 2005. "Green Clubs and Voluntary Covernance: ISO 14001 and Firms' Regulatory Compliance." American Journal of Political Science 49 (2): 235-248.

Potoski, M., and A. Prakash. 2009. Voluntary Programs: A Club Theory Perspective. Cambridge, MA: MIT Press.

Sam, A., M. Khanna, and R. Innes. 2009. "Voluntary Pollution Reduction Programs, Environmental Management, and Environmental Performance: An Empirical Study." Land Economics 85 (4): 692-711.

Sartzetakis, E., A. Xepapadeas, and E. Petrakis. 2012. "The Role of Information Provision as a Policy Instrument to Supplement Environmental Taxes." Environmental and Resource Economics 52 (3): 347-368.

Segerson, K 2013. "Voluntary Approaches to Environmental Protection and Resource Management." Annual Review of Resource Economics 5 (1): 161-180.

Segerson, K., and T. J. Miceli. 1998. "Voluntary Environmental Agreements: Cood or Bad News for Environmental Protection?" Journal of Environmental Economics and Management 36 (2): 109-130.

Sipic, T. (2010).Working Paper edn Eco-Labeling of Services: The Blue Flag.

Smith, J., M. Hurwitz, and ]. Howell. 2015. "Screening Mechanisms and Student Responses in the College Market." Economics of Education Review 44 (1): 17-28.

Soo, K. T., and C. Elliott. 2010. "Does Price Matter? Overseas Students in UK Higher Education." Economics of Education Review 29 (4): $553-565$.

Stefan, A., and L. Paul. 2008. "Does It Pay to Be Green? A Systematic Overview." The Academy of Management Perspectives 22 (4): 45-62.

Teisl, M. F., B. Roe, and R. L. Hicks. 2002. "Can Eco-Labels Tune a Market? Evidence from Dolphin-Safe Labeling." Journal of Environmental Economics and Management 43 (3): 339-359.

US Department of Education. Institute of Education Sciences, National Center for Education Statistics. Integrated Postsecondary Education Data Systems, [Online] 2015 http://nces.ed. gov/ipeds/.

van't Veld, K., and M. J. Kotchen. 2011. "Green Clubs." Journal of Environmental Economics and Management 62 (3): 309-322.

Vidovic, M., and N. Khanna. 2007. "Can Voluntary Pollution Prevention Programs Fulfill Their Promises? Further Evidence from the EPA's 33/50 Program." Journal of Environmental Economics and Management 53 (2): 180-195.

Welch, E. W., A. Mazur, and S. Bretschneider. 2000. "Voluntary behavior by electric utilities: Levels of adoption and contribution of the climate challenge program to the reduction of carbon dioxide." J. Pol. Anal. Manage 19 : 407-425.

Wooldridge, J. M. 2005. "Fixed-Effects and Related Estimators for Correlated Random-Coefficient and Treatment-Effect Panel Data Models." The Review of Economics and Statistics 87 (2): 385-390.

\section{Appendix: Interrupted Times Series Details}

For each signatory IHE, $i$, define the ACUPCC effective signing year ${ }^{37}$ as $k_{i}$. Normalize by the effective signing year so that

$$
\hat{T}_{i t}=T_{i t}-k_{i}
$$

represents the year relative to the effective signing year. We specify a bandwidth, $b$, and include all IHEs in the sample that are observed for $b$ years prior to and post signing. Then, for $\left|\hat{T}_{i t}\right| \leq b$, the baseline ${ }^{38}$ econometric model is

$$
Y_{i t}=\alpha+\gamma_{i}+\tau \times I\left(\hat{T}_{i t}>k_{i}\right)+\beta_{1} \times \hat{T}_{i t}+\beta_{2} \times \hat{T}_{i t} \times I\left(\hat{T}_{i t}>k_{i}\right)+\varphi_{t}+\varepsilon_{i t},
$$

where $\gamma_{i}$ are IHE fixed-effects, $I\left(\right.$.) represents the indicator function, and $\varphi_{t}$ are year fixed-effects (to account for common changes in the dependent variable over calendar years). For the baseline results, we set $b=4$; therefore, we include all IHEs with an effective signing year of 2009 or earlier so that each IHE has an equal number of observations prior to and post signing. Thus, $\tau$ is the effect of signing on the outcome variable, $\beta_{1}$ is the pre-signing slope, and $\beta_{2}$ is the change in the slope in the post-signing period relative to the pre-signing period.

\section{Appendix Tables}

Table 11: Summary statistics of DID sampling groups. 


\begin{tabular}{|c|c|c|c|c|c|c|c|}
\hline & \multirow[b]{2}{*}{ All IHEs } & \multicolumn{2}{|c|}{ Green Guide } & \multicolumn{2}{|c|}{ Signatories } & \multicolumn{2}{|c|}{ All 4-year IHEs } \\
\hline & & Signed & Not & 2007 & 2008-2013 & Signed & Not \\
\hline $\begin{array}{l}\text { Applica- } \\
\text { tions }\end{array}$ & $4,925.4$ & $8,521.5$ & $10,354.5^{*}$ & $7,652.2$ & $6,172 \cdot 6^{*}$ & $6,857.8$ & $3,931.0^{* * *}$ \\
\hline Admissions & $2,986.3$ & $5,145.2$ & $5,408.5$ & $4,598.1$ & $3,747.0^{*}$ & $4,141.1$ & $2,392.0^{* * *}$ \\
\hline Enrolled & $1,072.1$ & $1,728.3$ & $2,007.3$ & $1,537.2$ & $1,300.0$ & $1,409.8$ & $898.2^{* * *}$ \\
\hline $\begin{array}{l}\text { Common } \\
\text { application }\end{array}$ & 0.219 & 0.385 & 0.362 & 0.36 & 0.34 & 0.35 & $0.15^{* * *}$ \\
\hline $\begin{array}{l}\text { In-state } \\
\text { tuition }\end{array}$ & 16.99 & 17.4 & $20.5^{*}$ & 16.2 & 17.4 & 16.9 & 17.0 \\
\hline $\begin{array}{l}\text { Out-of-state } \\
\text { tuition }\end{array}$ & 20.7 & 23.7 & 25.4 & 22.7 & 22.0 & 22.3 & $19.9^{* * *}$ \\
\hline $\begin{array}{l}\text { HS } \\
\text { graduates } \\
(1,000 s)\end{array}$ & 106.8 & 113.3 & $133.7^{*}$ & 113.8 & 101.9 & 107.4 & 106.4 \\
\hline $\begin{array}{l}\text { Income per } \\
\text { capita } \\
(1,000 \mathrm{~s})\end{array}$ & 43.4 & 44.9 & 45.0 & 45.1 & 44.8 & 44.9 & $42.7^{* * *}$ \\
\hline $\begin{array}{l}\text { Undergrad- } \\
\text { uate } \\
\text { application } \\
\text { Fee }\end{array}$ & 53.3 & 64.3 & 67.9 & 61.7 & 58.7 & 60.1 & $49.6^{* * *}$ \\
\hline $\begin{array}{l}\text { Average } \\
\text { professor } \\
\text { salary } \\
(1,000 \text { 's })\end{array}$ & 94.39 & 109.6 & $118.9^{* * * *}$ & 104.2 & 101.8 & 102.9 & $89.9^{* * *}$ \\
\hline Private & 0.61 & 0.48 & 0.54 & 0.47 & 0.53 & 0.50 & $0.66^{* * *}$ \\
\hline $\begin{array}{l}\text { Number of } \\
\text { IHEs }\end{array}$ & 1036 & 208 & 105 & 163 & 189 & 352 & 684 \\
\hline
\end{tabular}

Notes: Statistics come from the 2005-2006 academic year, before the impact of ACUPCC signing takes place. Tuition, income, application fee and professor salary variables measured in constant 2014 dollars. The number of observations is slightly lower for the tuition, application fee, and professor salary variables.

* indicates means different at $10 \%$ level, $\quad * *$ indicates means different at $5 \%$ level, $\quad * * *$ indicates means different at $1 \%$ level.

Table 12: Regression results: levels.

\begin{tabular}{|c|c|c|c|c|c|c|}
\hline & \multicolumn{2}{|c|}{ Applications } & (3) & $\begin{array}{l}(4) \\
\text { sions }\end{array}$ & Enrollment & $\begin{array}{l}(6) \\
\text { ment }\end{array}$ \\
\hline Signed & $\begin{array}{l}183.68^{*} \\
(96.10)\end{array}$ & $\begin{array}{l}186.51^{*} \\
(101.52)\end{array}$ & $\begin{array}{l}87.63 \\
(55.21)\end{array}$ & $\begin{array}{l}76.83 \\
(52.50)\end{array}$ & $\begin{array}{l}19.50^{*} \\
(11.82)\end{array}$ & $\begin{array}{l}13.66 \\
(12.13)\end{array}$ \\
\hline $\begin{array}{l}\text { IHE-level } \\
\text { controls }\end{array}$ & No & Yes & No & Yes & No & Yes \\
\hline Observations & 12,353 & 11,216 & 12,353 & 11,216 & 12,350 & 11,214 \\
\hline$R$-squared & 0.988 & 0.987 & 0.984 & 0.987 & 0.989 & 0.990 \\
\hline
\end{tabular}

Notes: Table presents regression results from sample of all 4-year IHEs. Standard errors, clustered at IHE level, presented in parentheses. All specifications include IHE fixed effects, IHE-specific linear trends, and year fixed effects. IHE-level controls are common application, HS graduates, income per capita, undergraduate application fee, lagged in-state tuition, lagged out-of-state tuition and lagged professor salary. All monetary variables measured in constant 2014 dollars. $*$ denotes significance at 0.10 level. $\quad * *$ denotes significance at 0.05 level, $\quad * * *$ denotes significance at 0.01 level,

Table 13: Interrupted time series falsification tests.

\begin{tabular}{lllll}
\hline & $\mathbf{( 1 )}$ & $\mathbf{( 2 )}$ & $\mathbf{( 3 )}$ & $\mathbf{( 3 )}$ \\
& Application fee & Ln application fee & Ln tuition & \begin{tabular}{l} 
\% tenure track \\
\hline Signed
\end{tabular} \\
& 0.475 & -0.00540 & -0.00527 & -0.000495 \\
Observations & $(0.837)$ & $(0.0105)$ & $(0.0122)$ & $(0.00700)$ \\
$R$-squared & 2,698 & 2,582 & 2,697 & 2,638 \\
Number of IHEs & 0.348 & 0.392 & 0.21 & 0.035 \\
\hline
\end{tabular}


Notes: Table presents result from interrupted time series models, with dependent variable listed. Undergraduate application fee is measured in constant 2014 dollars and tuition is measured in thousands of constant 2014 dollars. Each specification includes linear trend variables. The bandwidth of 4 years in these models means we include IHEs signing in 2009 or earlier. Standard errors, clustered at IHE level, presented in parentheses. Each regression includes year and IHE fixed effects. * denotes significance at 0.10 level.

** denotes significance at 0.05 level,

*** denotes significance at 0.01 level, 